\title{
Validity and Effects of the Arbitration Agreement in Domestic and International Law of Iran and Arbitration Rules of the International Chamber of Commerce
}

\author{
Hamzeh Esfandiari Bayat ${ }^{1}$ \\ ${ }^{1}$ Department of Law and Humanities, College of Law, Shiraz Branch, Islamic Azad University, Shiraz, Iran \\ Correspondence: Hamzeh Esfandiari Bayat, Department of Law and Humanities, College of Law, Shiraz Branch, \\ Islamic Azad University, Shiraz, Iran. E-mail: Hamzeh.esfandiari.bayat@gmail.com
}

Received: February 14, 2016

Accepted: March 8, 2016 Online Published: March 31, 2016

doi:10.5539/jpl.v9n2p146

URL: http://dx.doi.org/10.5539/jpl.v9n2p146

\begin{abstract}
By more familiarity of people to the positive aspects of arbitration, the tendency to the dispute of arbitration has been more, but every time this issue is not possible simply because the parties may not have the required qualifications to adjust the arbitration agreement or the law that parties have considered ruling on the arbitration agreement, is invalid or if the agreement is adjusted in Iran due to the explicit opposition of law ruling to Iran's law, agreement loses its validity; Which this issue can follow the effects such as competent of judicial authorities in handling disputes. So the familiarity of parties can be important with the conditions of validity and effects of arbitration agreement. In this article, it is tried to be investigated and analyzed the validity conditions and the effects of arbitration agreements in domestic and international law of Iran and the rules of arbitration of the International Chamber of commerce separately and ruled procedure.
\end{abstract}

Keywords: International Chamber of Commerce, courts, arbitration agreement, the New York Convention, competency

\section{Introduction}

Arbitration agreement is an independent agreement or as stipulation that by the parties is adjusted and during that competency of investigating specified disputes in contract is rewarded to impartial and independent person or third party, so the qualifications of the parties and the familiarity with law that parties intend to arbitration agreement is function with the law is important because the validity or invalidity leads to effects that may be caused the violation of the rights of one party. On the subject of research, numerous articles presented that each has investigated slightly and distinctly effects or validity of the arbitration agreement; But in any articles is done investigating validity and effects of the arbitration agreement and comparing and analyzing both domestic and international arbitration of the International Chamber of Commerce; So the aim of this research is familiar with this important issue in comparative and separated state by relying the concerned authorities votes and views of jurists.

\section{Validity of Arbitration Agreement}

One of the conditions of international standard of arbitration agreement is validity. Validity of the arbitration agreement is measured according to the law which the parties of the arbitration agreement have subjected of it. The law governing the arbitration agreement can be different from the law governing the nature of commercial contracts (Amir Moezi, 2009, p. 492).

So, invalid agreement ultimately leads to the competency of court in investigating the disputed subject.

\section{The Validity Conditions of Arbitration Agreement}

Article 33 of the Law on International Commercial Arbitration has mentioned the annulment of the arbitration award that two of which related to the validity of the arbitration agreement:

1. one of the parties not have qualification.

Qualification of Iranian citizens under Articles 1207 to 1217 of the Civil Code and Qualification of foreigners is subject to national law of same person. However, in accordance with Article 962 of recent mentioned law, if one foreign national person does in legal action in Iran if the person not has the qualification to do that action 
according to the law of his government or has incomplete qualification, that person for the action will consider qualified and if regardless of his foreign citizenship in accordance with Iranian law also consider him as qualified to do it.

But in the case of legal entities, must be scrutinized carefully to ensure that signer of contract from legal entity has the qualification and competency of referred claims and current disputes or future of legal person to judge that the confident is usually obtained through consciousness of Statute of legal person and other documents of delegation of representative (Shiravi, 1999, p. 67).

2. Arbitration agreement under the law that the parties have considered governing the agreement isn't valid and in the case of silence of ruled law, is totally opposed to Iranian law.

Although parties are free to have more control on arbitration matters but not from the perspective of parties and not from the efficiency of arbitration method is not desirable that the freedom of the will of parties is infinite. Will arbitration of parties with regard to public order, natural justice, support of the weaker side and go to court if necessary, has been identified and accepted all over the world (kakavand, 1388, p. 5).

In addition, Article 34 of the aforementioned law have considered arbitration award in three cases essentially void and unenforceable:

1) If the main of the dispute in accordance with Iranian law is not settled through arbitration.

2. If the provisions of vote is contrary to public order or good morals or peremptory norms of the law.

2) 3. Issued arbitral awards in respect of immovable property located in Iran is in conflict with existing laws Islamic Republic of Iran or with the provisions of valid official documents, unless in the latter case "arbitration" is the right to compromise.

From the mentioned cases two latter cases about the arbitration award and the third case about arbitration agreement is the foundation of arbitration proceedings.

Considering the above, the judge while dealing with the existence subject and validity of the arbitration during and when one of the parties documented to the arbitration condition and, of course, " arbitral award has not been issued yet, should find the validity or invalidity of the arbitration agreement in regulations that is in Article 33 concerning the annulment of the arbitral award.

Thus, in accordance with the regulation of Iran's law, Iranian judge in the case of the three above mentioned cases will consider null and void the arbitration agreement.

The aforementioned three conditions are in Article 5 of the New York Convention. The difference is that instead of the above paragraph in Article 5 of the New York Convention, we read such this:

"The parties of the arbitration agreement under their respective law due to something have been incapable or mentioned agreement, according to law that is in accordance to the parties agreement governing this agreement or in the absence of any indication on the parties agreement on the law governing, according to the law of the country that arbitral award is issued there, is invalid."

A) Comparing law regulations of international commercial arbitration and the New York Convention on the validity of the arbitration agreement.

According to the above cases, law and international commercial arbitration and the New York Convention are common in the following bases:

1. If the non-qualification of each of the parties, the arbitration agreement is void.

2. The law governing the arbitration agreement is a law that the parties have determined.

3. If the matter isn't referred to arbitration under the law of the country, the arbitration agreement is void.

Differences in international commercial arbitration law and the New York Convention on the implementation of the above-mentioned regulations are as follows:

1. In Iran's law, has not been determined that in accordance with what law is established the qualification of the parties. It should be noted that Iran's law applies in a situation that at least one of the parties of the arbitration agreement is not a citizen of Iran. Therefore, in the case that one of the parties is Iranian and other part is foreign national and on the Iranian side, Iran's law and on foreign part government law is applied and in the case that both sides are foreign nationals, their respective government law will govern on their qualification and the government "the government's law of the parties" on the issue of qualification is what the New York Convention has clearly stated. 
2. In the New York Convention after announcing that the law governing the validity of agreement is agreed of the parties, adding that if "the parties' silent on the governing law," the law of the place of issued of arbitration award will be criteria. In Article 33 of the Iran's law "if the silence of governing law" that according to the law of UNCITRAL and other reasons, it seems that the expression "if the silence of the parties about the governing law" has been correct and considered.

3. In any case, given the silence of the parties about the legislation governing under the Iran's law, arbitration agreement must not be contrary to Iran's law, but in the New York Convention as previously was pointed "it shouldn't be against the law of the country, that the arbitral award was issued in it. With respect to the latter mentioned constraint in the New York Convention refers to a case that arbitral award is issued previously. It may not be applicable to a case that parties have not referred to arbitration yet. Although in implementing Convention in New York, states' courts sometimes by developing the concept not considered the arbitration law as the place where the verdict will be stated (Shariat Bagheri, 2001, Pp 83-87).

\section{Validity Constrains of Arbitration Agreement}

\subsection{Iran's Rights}

In accordance with Article 139 of the Constitution: "peace of claims relating to public and state property or referring it to arbitration in every case is dependent upon the approval of the Council of Ministers and the Parliament must be informed. In a case that litigant is an alien and in important internal matter should also be approved by parliament. Law will specify the important cases ". In this principle isn't mentioned the name of the state apparatus. This means that no matter the litigant of arbitration is state or non-state, but what is the important are the public funds and decision making on peace or referring lawsuits related to them to arbitration, even though the property is non- state in persons. Conversely, if property other than public funds is in the capture of the government agencies, the mentioned conditions in principal 139 and Article of law of civil procedure for referring a dispute about them to the arbitration isn't included them to be obligatory (Hendi, 2007, p. 66).

The Council of Ministers at the meeting dated 1997 according to principle one hundred and thirty-eighth constitution of the Islamic Republic of Iran on referring internal litigants to arbitration adopted "Council of Ministers authority the issue of one hundred and thirty-ninth constitution about referring internal litigants to arbitration provided that the relevant ministers on the subject of litigant is presented in government's economic Commission Board "(Maffei and Kavyar, 2013, p. 199).

The inclusion of authority of state and public organizations in referring litigants to their arbitration in the Constitution and subject to parliament approval -in addition to the approval of the Council of Ministers is the reason of importance that the framers had considered to the jurisdiction of domestic courts in handling litigants. However, should not assume that the solution provided in Article 139 is a strange invention. In internal Iran's law, before the revolution, also governmental organizations were banned from referring their disputes to arbitration. According to Article 29 regulation of public transactions approved property laws of the Commission of the National Assembly dated 1955, in any of the treaties shouldn't be mentioned the right of referring to arbitration, while the legislator explicitly had prohibited government institutions from arbitration. But at least innovation of Constitution is that to the government or government agencies are able to refer to arbitration, it is necessary in addition to approved by the Cabinet _ as in the former was usual _ council approval requests, disputes that are intended to refer to arbitration before in the court of Justice is raised or not.

However, Article 139 of the Constitution _ as is set, raises several questions. Is the principal 139 on necessity to approve referring litigants to arbitration, retroactive or not?

In our view the contents of Article 139 cannot be retroactive because the parties of arbitration agreement Whatever is their intentions_ has signed the contract according to the rules and regulations of setting time and sign it and by reliance on the principles and rules. Arbitration agreements which is signed before the adoption of new constitution between the government and the Iranian governmental organizations and foreign companies, does not require to legislative approval. The principle to not retroactive of law that in Article 4 of the Civil Code of Iran emphasized is also true about the agreements relating to referral to litigant of government and governmental organizations to arbitration. According to the article: The effect of the law to the future and does not affect the law than its predecessor, unless special provisions are taken to this issue, as mentioned in Article 139 _as we said_not mentioned at all that the regulation of mentioned principle to litigants before its approving is required to be observed (Skini, 1990, pp. 35 and 36).

Can it be said that legislator is necessitated the Parliament intervention only if due to the implementation of an international contract, dispute occurs between the government and the relevant government agencies and foreign companies? Isn't it necessary Approval of the Assembly before making difference and litigant? If accepted that 
the necessity of Approval of the Assembly is when the dispute and litigant has been created and therefore it is necessary that the dispute and litigant referred to arbitration, we should accept that public organizations can, while signing commercial contracts with foreign parties accept that in the event of a dispute, the matter is submitted to arbitration, without the need to approval of the arbitration clause that in this way is signed.

In our opinion, Article 139 of the Constitution _ even willing to it_is intended to referring public dispute with foreigners to absolute arbitration. In other words, accept the referral of litigants between the parties from the Iranian government needs to approval parliament, What during the accepting arbitration means during the signing of the original contract _ when dispute isn't made yet _ what then, after the conflict, in each case, the question must be approved by the parliament and by its approval, otherwise the arbitration condition is void if is in the contract and if there isn't, it cannot be _ in case of dispute _ referred to arbitration (Skini). Because the Iran's party with no reference to the principle of contract acted to its detriment and relying on them after the conflict is contrary to international conventions and does not seem to be accepted.

But the General Board of Administrative Justice Court in Verdict No. 138-139, dated 2012 against Sadrottosif theory has commented: "Derived from Article 139 of the Islamic Republic of Iran's constitution provides" peace of litigants relating to public and state property or its referral to arbitration in every case is subject to approval by the Council of Ministers and must inform the Parliament, in cases that the parties is foreign and in important cases should be approved by parliament. Important cases determined by law "principally government employees at the time of signing contract of arbitration are obliged to obtain the decree of the Council of Ministers or the Parliament. Considering that the protested approval is issued after adjusting arbitration contract and the provisions of Article 139 of the constitution does not follow in it, is specified against the law and with reference to paragraph one of Article 19 and Article 42 of the Administrative Justice Court will be void. ".

\subsection{Rights of Other Countries}

In some countries, it is stated that the government and public organizations can refer to arbitration in business relations with foreign companies, provided that they comply with certain conditions and precautions which the law is determined them. The nature of these precautions and conditions is different. In Colombia, for example Supreme Court has stated such that referral to international arbitration is possible provided that arbitration is done in Columbia. This principle also applies in Ecuador and Peru, although more recently in some oil contracts is predicted that arbitration will be done in London in accordance with the Arbitration Rules of the International Chamber of Commerce.

In Egypt, both domestic and international arbitration will be accepted. But oil contracts are distinguished among the case that the government is the signer of the contract and the case that the government is not doing this important issue: In the first case, arbitration shall be conducted in Egypt and based on domestic arbitration law. However, if the government through the National Oil Company prepares and signs the contract, is often referred to the Arbitration Rules of the International Chamber of Commerce. That's the tradition that Egypt since the signing of contracts with some Western companies such as Philips and Pan American has observed. Venezuela country_for example_ has prohibited arbitration for government absolutely (Skini)

\section{Effects of Arbitration Agreement}

Agreed to arbitration, either independently or in the form of contract stipulation is effective only to those who have set it and has no effect against third parties. In fact, under Article 457 of the Civil Procedure Code. "Third party who against the law was attended to justice or before or after referring dispute to arbitration entered to conflict, it can compromise with main parties to refer the matter to arbitration and appointing arbitrator or appointed arbitrators, and if the agreements are not obtained, his litigants will be dealt to the provisions independently "(Karimiyan, 2013).

\subsection{Commitment and Obligation of the Parties to Referring Dispute to Arbitration}

After occurring conflict if the arbitration agreement is existed, the parties are obliged to act through arbitration to settle their disputes unless disregarded referring to arbitration with agreement. This is recognized in $1958 \mathrm{New}$ York Convention and 1961 Geneva Convention. The conventions want the member of states to effort to enforce arbitration agreements.

Mostly legal systems have predicted mechanisms for combating the person that avoid this issue. For example, in the British legal system if one of the parties refuses from appointing arbitrator, the same referee can act as the common referee. This sentence is thus justified when the person refuses from appointing arbitrator the right of appointing arbitrator is deprived. In Romano-Germanic legal is usually predicted an appointed official that in the event of any fault in arbitration, he comes in to ace. If one of the parties in Iran's rights refuses from appointing 
arbitrator under Articles 459 and 460 A..D.M beneficiary can refer to the court for appointment of arbitrator. But if the parties do not want to appoint their arbitrator after dispute, the subject will be canceled and despite the compromise of parties on the principle of arbitration, the parties do not want or cannot nominate its arbitrator, there is no cause for intervention of court (Mohajeri, 2019, p. 200).

\subsection{Commitment and Obligations of Third Parties to Referring Dispute to Arbitration}

After adjusting contracts in some cases, arbitration condition to resolve disputes relating to contract is included in contract that during which the parties will be obliged to refer their litigant to arbitration in the event of a dispute. But in some cases, the original contract will be awarded to a third party or by the death of one of the parties the contract will be transferred to his heir. Here, is the heir or transferee must adhere to the arbitration clause?

\subsubsection{Rights of Iran}

\subsubsection{The Heir}

The provisions of Article 481 of the Civil Procedure Code are considered the death of one of the parties to the deterioration of arbitration. Of course, nullifying the subject of arbitration (Shokri, 2013, p. 315) and bankruptcy and liquidation of the legal person should be regarded as examples of the latter Article (Zeraat, 2004, p. 1310). So if arbitration is agreed while the necessary contract or even contract in Article $10 \mathrm{Gh}$. M, with the death of one of the parties of the transaction, although remain valid in the right of heirs, however, the arbitration clause of its attaching is removed and means that the forcible transfer of the necessary contract doesn't cause the transfer of arbitration clause contained in it. Some authors in justifying this decision have argued that the arbitration agreement is related to the people of the transaction and validity of party to the contract is signed and as financial commitments cannot be transferred to heirs and is vested with the individual (Vahedi, 2007, p. 209). But in contrast some not considered the legal order as correct (Sadr Zade Afshar, 2014, p. 388) and others have stated that should be distinguished between the case that the arbitration clause by dealers determined and the case that the parties without determine and specify the arbitrator predict the arbitration. Basically, when the parties without specifying a particular arbitration, they agreed that their future disputes is resolved through arbitration, cannot be claimed that such an agreement is vested with the individual because the arbitrator has not been determined yet to his personality is concerned of parties to the transaction, dealers personality will not affect in this respect, and being personal of arbitration agreement in such cases is unacceptable crucially. But, if in justification of not extending arbitration clause to general vicar (heirs of the contract) documented to the independence of the arbitration clause, the mentioned rule can be justified in a recent article (Shoaryan, 2009, p. 311).

\subsubsection{Transferee}

In transferring consequential contract, subject of transfer isn't the arbitration clause and regulations in this area will not be considered. In this regard, it may be argued that the independence of the arbitration clause requires that by the consequential transfer of contract, the arbitration clause fails, and no extended to specific vicar (Shoaryan, P 312). So in terms of voluntary transfer of contract, arbitration clause implicitly is transferred.

\subsubsection{Arbitration of International Chamber of Commerce}

Chamber rules on the validity of the arbitration agreement are silent on the transfer of the original contract so it would be the cases that should be referred to the regulations of the country. But in practice in Verdict No. 2626 the Court of Arbitration ICC, the arbitrators voted such that transform the company with limited liability to corporation does not cause that the arbitration agreement to the new company is invalid (Emamipoor, 2011)

\subsection{Empowers the Competency to Arbitrator or Arbitrators}

\subsubsection{Internal Arbitration of Iran}

According to Article 473 of the Civil Procedure Law, after the signing of the arbitration agreement, the arbitrator or arbitrators are not bound to accept arbitration if accepted, they not have the right to resign unless they have a valid reason (Beheshti \& Mardani, 2006, p. 375). Article 473 indicates that accepting arbitration isn't obligation for arbitrator, but doing it after announcing accepting is obligation. Because after acceptance, private contract between him and the person that has chosen him is signed. But if not accept arbitration, not have responsibility because even if the arbitrator or appointed arbitrators by the court are appointed are not bound to accept arbitration but when they accepted subject to the general rules, contracts and commitments due to them (Mohajeri, p. 253). 


\subsubsection{International Trade Arbitration of Iran}

According to paragraph 1 of the 16th International Commercial Arbitration Act:

An arbitrator can make decision about his competence as well as about the existence or validity of the arbitration agreement. The arbitration clause that is partly in a contract in terms of implementation of this law is considered as an independent agreement, the decision of the arbitrator regarding the invalidity of the contract and ineffective of contract will not mean invalidity of arbitration clause contained in the contract.

\subsubsection{Arbitration of International Chamber of Commerce}

International Chamber of Commerce has its own arbitration rules and on the basis of Article 6 the Arbitration Court is obliged to decide about the existence of the arbitration agreement and scope of arbitration. If the Court is satisfied that an arbitration agreement under the rules is existed, arbitration continues. Then tribunal formed and again about the existence and validity of the arbitration agreement, all necessary investigations are done and in the case of confirmed, under the predicted rules of chamber, disputes are investigated.

\subsection{Disqualification from State Courts}

\subsubsection{Internal Arbitration of Iran}

In the Civil Procedure Code, the rejection of the dispute by the judicial authorities in the case of setting the arbitration agreement doesn't exist. So it seems given that court is an official reference to investigate complaints has general competency and existence of arbitration agreement and without objection of parties could not be disqualified; But if it would be objectionable, the court acted to issue the order of not auditing dispute (Mandegar). Of course, the Legal Department of the Judiciary in theory 7/ 2421 dated 2004 has the opposite view: "If in the contract, the parties are required to refer to arbitration in case of dispute, but before referring to arbitration, the parties in the General Court venture into a lawsuit, the raised lawsuit does not have legally audibility "(Masihi, 2008, p. 349). Theory of Legal Department does not seem very logical because by referring one of the parties to judicial authorities and the silence of other party and the absence of objection from him by believing some professors (Mandegar) is considered a practical compromise, and provides the fields of Court proceeding. As the first branch of the Supreme Court in verdict No. 2485- 1932 states: "Written consent on referring arbitration may be implied obligation and evidence as after arbitration contract, one side raised the issue on the Court and the other side does not raise objection that the litigant is in the competency of arbitrator"(Hossaeini, 2002, p. 281).

It should be noted that the lack of competency of the court is not absolute and the court depending on the legal system of the country maintains its competency to intervene in some matters (such as selecting arbitrator, etc.).

Referring to various international documents show that despite an arbitration clause, courts can intervene in individual cases. For example, according to the International Commercial Arbitration Act, the involvement of the court is as follows:

Intervention before the start of proceedings: In case of refusal of the parties to present in arbitration or the appointment of arbitrator (article 11 paragraph 3 and 4), intervention to handle injury dispute against the arbitrator (paragraph 3 of Article 13), the inability or failure of arbitrator in doing duty (Article 14), protesting the lack of competency of arbitrator (paragraph 3 of Article 16).

Intervention in arbitration: intervention for the issuance and implementation of security arrangements (Article 6 refers to Article 9).

Intervention after issued the verdict: intervention to void the verdict of arbitrator (Article 33), intervene to enforce verdict of arbitrator (Article 35)

\subsubsection{International Commercial Arbitration of Iran}

Arbitration agreement obliges the parties to referring dispute the subject of agreement to arbitration and from same way and in law enforcement, arbitrator finds the competency of investigating and issued of verdict and thus the state court loses the competency to investigate dispute subject of arbitration agreements (Shams, 2006, p. 529). Law on International Commercial Arbitration in Article 8 provides: "The court that the dispute of subject of arbitration agreement is brought near it, in the case of request of one of the parties by the end of the first session of the trial, dispute of parties is referred to arbitration unless ascertains that the arbitration agreement is void, or unenforceable. Raising dispute in court not prevents the start or continuation of the arbitration proceedings and issued verdict. "Of course, rejecting dispute by the court is upon the request of one party until the end of the first session of the court, otherwise the court will continue to proceedings. So it seems that according to the law, the court cannot issue the disqualification especially when one of the parties in court 
proceedings and the other does not raise objection, this could imply an implicit withdrawal of the parties to referring the subject to arbitration.

\subsubsection{Arbitration of International Chamber of Commerce}

Article 2 of the Convention in New York, predicted that "If any dispute is raised in the courts of the Contracting States that the parties about the main subject of litigation have arbitration agreement with the meaning set in this Article, court on the request of the parties will refer the litigant to arbitration unless in cases that according to the discretion of the court, arbitration agreement is void or without effect or ineligible to run."

\section{Conclusion}

Disputes referral to arbitration based on arbitration agreement or arbitration condition is the contract which the parties have provided at the time of setting original contract. The importance of setting arbitration agreement is noteworthy in this respect that may be some disputed cases due to not pointing in the contract do not have the ability to refer to arbitration or the parties have been incapable to set the contract or without regard to the law governing the arbitration, the contract set as that according to recent mentioned law is invalid. The parties may face limitations in referring the matter to arbitration, such as referral of litigants relating to public and state property to arbitration that in Iran's rights must be respected the constitution conditions in Article 139 and Article 457 of the Civil Procedure Code. There are hard or same regulations in other countries rights. The consequences of the invalidity of the arbitration agreement is to accept the related litigants from the judicial authorities and effects of a valid arbitration agreement is rejecting litigants by the courts, granting competency to arbitrator or arbitrators and obligations of the parties to referring dispute to arbitration.

\section{References}

Amir Moezi, A. (2009). international arbitration in commercial disputes (2nd ed.). Tehran: Justice.

Beheshty, M. J., \& Mardani, N. (2006). Code of Civil Procedure (Vol. II, 1st ed.). Tehran: Mizan.

Emamy Pour, M. (2011) transfer arbitration condition. Retrieved from http://memamipour.blogfa.com/post/16 reference date 2015

Hendi, S. A. (2007). review the extending provisions of Article 139 of the constitution to property of public companies. Journal of Law of Justice, 61.

Hosseini, S. M. R. (2002). Code of Civil Procedure on judicial procedures (1st ed.). Tehran: Majd.

Kakavand, M. (2009). freedom of the will of the parties in international commercial arbitration, arbitration magazine, No. 32 .

Karymiyan, M. (2013). the arbitration agreement, referred in 2015. Retrieved from http://karimiyangaze.persianblog.ir/post/18

Mafey, H., \& Kavyar, H. (2013). the legal sources of private international law and arbitration (1st ed.). Tehran: Majd.

Masihy, M. (2008). the Civil Procedure Code in the mirror of judicial decisions and advisory opinions (1st ed.). Tehran: Khorsando.

Mohajery, A. (2010). detailed in the Code of Civil Procedure (Vol. IV, 2nd ed.). Tehran: Fekrsazan.

Sadrzadeh Afshar, S. M. (2014). civil procedure and commercial - public and revolutionary courts, printing 12 , Tehran: SID.

Shams, A. (2006). Code of Civil Procedure (Volume III, 5th ed.). Tehran: Drak.

Shariat Bagheri, M. J. (2001). Effect of Iran's accession to 1958 New York Convention on the recognition and enforcement of foreign arbitral awards. Justice Law Journal, (36).

Sharyan, E. (2009). the transfer of contracts, first printing. Tabriz: Fruzesh.

Shiravi, A. H. (1999). set the arbitration agreement according to the International Commercial Arbitration, Journal of Higher Education Complex of Qom, the third number.

Shokry, M. (2013). the topics of the Code of Civil Procedure, referring date 2015. Retrieved from www.ekhtebar.com/wp-content/plugins/download.../download.php?id=8

Skini, R. (2010). the authority of governments and public organizations in referring to International Commercial Arbitration, Faculty of Law and Political Science at Tehran University, No. 25.

Vahedy, G. (2007). Code of Civil Procedure (Book III, 4th ed.). Tehran Mizan. 
Zeraat, A. (2004). the Civil Procedure Code in the current legal order (1st ed.). Tehran: third line.

\section{Copyrights}

Copyright for this article is retained by the author(s), with first publication rights granted to the journal.

This is an open-access article distributed under the terms and conditions of the Creative Commons Attribution license (http://creativecommons.org/licenses/by/3.0/). 